\title{
Effects of feeding hull-less barley on production performance, milk fatty acid composition, and nutrient digestibility of lactating dairy cows
}

\author{
Y. Yang, ${ }^{*}$ G. Ferreira, ${ }^{* 1}$ C. L. Teets, ${ }^{*}$ B. A. Corl, ${ }^{*}$ W. E. Thomason, $\dagger$ and C. A. Griffey $†$ \\ *Department of Dairy Science, and \\ †Department of Crop and Soil Environmental Sciences, Virginia Tech, Blacksburg 24061
}

\section{ABSTRACT}

The objectives of this study were to evaluate production performance, milk fatty acid composition, and nutrient digestibility in high-producing dairy cows consuming diets containing corn and hull-less barley (cultivar Amaze 10) in different proportions as the grain source. Eight primiparous and 16 multiparous Holstein cows were assigned to 1 of 4 diets in a replicated $4 \times 4$ Latin square design with 21 -d periods. Cows were fed once daily $(1200 \mathrm{~h})$ by means of a Calan gate system (American Calan Inc., Northwood, NH). All diets contained $\sim 20 \%$ grain (dry matter basis). Treatments consisted of $100 \%$ corn (0B), $67 \%$ corn and $33 \%$ hull-less barley (33B), 33\% corn and $67 \%$ hullless barley (67B), and 100\% hull-less barley (100B) as the grain sources. Total-tract nutrient digestibility was estimated using lanthanum chloride $\left(\mathrm{LaCl}_{3}\right)$ as an external marker. Dry matter intake differed quadratically among treatments, being lowest for $67 \mathrm{~B}$ and highest for $0 \mathrm{~B}$ and 100B. Feeding hull-less barley did not affect milk yield, and milk fat concentration differed cubically among treatments. The cubic response was attributed to the higher milk fat concentration observed for the diet containing 67B. Neither the concentrations in milk of protein and lactose nor the yields of protein and lactose differed among treatments. The proportion of de novo synthesized fatty acids in milk did not differ among treatments. The apparent total-tract digestibility of dry matter, crude protein, and neutral detergent fiber did not differ among treatments. Although a quadratic effect was observed, starch digestibility was minimally affected by treatments. In conclusion, this study indicates that hull-less barley grain is as good as corn grain as an energy source when formulating diets for high-producing dairy cows.

Key words: hull-less barley, hulless barley, cereal grains, digestibility, milk fatty acids

Received November 1, 2016.

Accepted December 30, 2016.

${ }^{1}$ Corresponding author: gonf@vt.edu

\section{INTRODUCTION}

Cereal grains are a major energy source in diets for lactating dairy cows. Cereal grains contain high concentrations of starch, a component that is almost completely and uniformly digested in the gastrointestinal tract when adequately processed (Nocek and Tamminga, 1991; Ferreira and Mertens, 2005; Ferraretto et al., 2013). Among cereal grains, differences exist for degradation rate of starch in the rumen. For instance, starch degradability in the rumen is greater for wheat and barley than for corn and sorghum (Herrera-Saldana et al., 1990; Overton et al., 1995; Yang et al., 1997b).

Current recommendations from NRC (2001), which are based on diets containing dry ground corn grain, suggest that dietary NDF should be increased when readily available starch sources replace dry ground corn in the diet. Citing a study from Beauchemin (1991), the NRC (2001) established that the NDF requirement for dairy cows should be increased to $34 \%$ NDF when feeding diets containing barley as the grain source. For other starch sources, however, insufficient information exists to give specific recommendations (NRC, 2001).

Even though recent in situ and in vitro studies exist (Fellner et al., 2008; Yang et al., 2013a,b), hull-less barley is one starch source for which insufficient production performance information exists (Yang et al., 1997a,b) to provide specific dietary recommendations (NRC, 2001). Hull-less or "naked" barley differs from traditional hulled barley in that the loose husk covering the caryopsis is removed during combine threshing and cleaning of the grain (Thomason et al., 2009). Due to the loss of the hulls, hull-less barley grain can have 10 to $14 \%$ less NDF than hulled barley grain. Yang et al. (1997a) fed low-forage diets containing 50\% cereal grains (DM basis) to lactating dairy cows and reported a lower DMI and milk yield when hull-less barley grain replaced corn grain. In another study, Yang et al. (1997b) did not observe differences in production performance nor NDF and starch digestibilities when feeding diets containing either corn or hull-less barley as the grain source. Based on the limited information, benefits or shortcomings of including hull-less barley in 
Table 1. Ingredient and chemical composition of diets (\%, DM basis)

\begin{tabular}{|c|c|c|c|c|}
\hline \multirow[b]{2}{*}{ Item } & \multicolumn{4}{|c|}{ Diet $^{1}$} \\
\hline & 0B & $33 \mathrm{~B}$ & $67 \mathrm{~B}$ & $100 \mathrm{~B}$ \\
\hline \multicolumn{5}{|l|}{ Ingredient } \\
\hline Corn silage $^{2}$ & 36.0 & 35.9 & 35.9 & 35.9 \\
\hline Alfalfa hay ${ }^{3}$ & 15.3 & 15.2 & 15.2 & 15.2 \\
\hline Corn grain ${ }^{4}$ & 20.2 & 13.6 & 6.7 & - \\
\hline Hull-less barley grain ${ }^{5}$ & - & 6.8 & 13.9 & 20.6 \\
\hline Soybean meal & 12.7 & 12.7 & 12.6 & 12.6 \\
\hline Soybean hulls & 7.7 & 7.7 & 7.6 & 7.6 \\
\hline Corn dry distiller grains with solubles & 4.2 & 4.2 & 4.2 & 4.2 \\
\hline EnerGII ${ }^{6}$ & 0.8 & 0.8 & 0.8 & 0.8 \\
\hline Sodium bicarbonate & 1.0 & 1.0 & 1.0 & 1.0 \\
\hline Bentonite & 0.9 & 0.9 & 0.9 & 0.9 \\
\hline Salt & 0.5 & 0.5 & 0.5 & 0.5 \\
\hline Magnesium oxide & 0.2 & 0.2 & 0.2 & 0.2 \\
\hline Trace mineral premix ${ }^{7}$ & 0.4 & 0.4 & 0.4 & 0.4 \\
\hline Vitamin $\mathrm{ADE}^{8}$ & 0.04 & 0.04 & 0.04 & 0.04 \\
\hline Vitamin $\mathrm{E}^{9}$ & 0.003 & 0.003 & 0.003 & 0.003 \\
\hline Rumensin $90^{10}$ & 0.006 & 0.006 & 0.006 & 0.006 \\
\hline \multicolumn{5}{|l|}{ Nutrient } \\
\hline $\mathrm{OM}$ & 92.1 & 91.9 & 91.8 & 91.6 \\
\hline $\mathrm{CP}$ & 17.5 & 17.8 & 18.2 & 18.6 \\
\hline NDF & 30.1 & 30.2 & 30.4 & 30.5 \\
\hline Forage NDF & 18.4 & 18.3 & 18.3 & 18.2 \\
\hline Starch & 30.7 & 29.9 & 29.0 & 28.2 \\
\hline \multicolumn{5}{|c|}{$\begin{array}{l}{ }^{1} 0 \mathrm{~B}=100 \% \text { corn grain; } 33 \mathrm{~B}=67 \% \text { corn grain and } 33 \% \text { barley grain; } 67 \mathrm{~B}=33 \% \text { corn grain and } 67 \% \text { barley } \\
\text { grain; } 100 \mathrm{~B}=100 \% \text { barley grain. }\end{array}$} \\
\hline \multicolumn{5}{|c|}{${ }^{2}$ Corn silage composition: $36.8 \% \mathrm{DM}, 9.1 \% \mathrm{CP}, 33.7 \% \mathrm{NDF}$, and $42.3 \%$ starch. } \\
\hline \multicolumn{5}{|c|}{${ }^{3}$ Alfalfa hay composition: $85.3 \% \mathrm{DM}, 22.6 \% \mathrm{CP}, 46.7 \% \mathrm{NDF}$, and $3.0 \%$ starch. } \\
\hline \multicolumn{5}{|c|}{${ }^{4}$ Corn grain composition: $1.9 \%$ ash, $8.8 \% \mathrm{CP}, 10.6 \% \mathrm{NDF}$, and $65.4 \%$ starch. } \\
\hline \multicolumn{5}{|c|}{${ }^{5}$ Hull-less barley grain composition: $3.2 \%$ ash, $14.3 \% \mathrm{CP}, 12.6 \% \mathrm{NDF}$, and $58.2 \%$ starch. } \\
\hline \multicolumn{5}{|c|}{${ }^{6}$ Calcium salts of fatty acids (Virtus Nutrition LLC, Corcoran, CA). } \\
\hline \multicolumn{5}{|c|}{$\begin{array}{l}{ }^{7} \text { Contained } 22.25 \% \text { calcium; } 7.50 \% \text { magnesium; } 2.75 \% \text { potassium; } 3.90 \% \text { sulfur; } 1.50 \% \text { manganese; } 1.50 \% \text { zinc; } \\
9,500 \mathrm{mg} / \mathrm{kg} \text { of iron; } 2,500 \mathrm{mg} / \mathrm{kg} \text { of copper; } 200 \mathrm{mg} / \mathrm{kg} \text { of iodine; } 200 \mathrm{mg} / \mathrm{kg} \text { of cobalt; } 66 \mathrm{mg} / \mathrm{kg} \text { of selenium; } \\
227,273 \mathrm{IU} / \mathrm{kg} \text { of vitamin } \mathrm{A} ; 136,364 \mathrm{IU} / \mathrm{kg} \text { of vitamin } \mathrm{D}_{3} ; 636 \mathrm{IU} / \mathrm{kg} \text { of vitamin E. }\end{array}$} \\
\hline \multirow{2}{*}{\multicolumn{5}{|c|}{${ }^{8}$ Contained $3,500 \mathrm{IU} / \mathrm{kg}$ of vitamin $\mathrm{A} ; 950 \mathrm{IU} / \mathrm{kg}$ of vitamin $\mathrm{D}_{3} ; 2,000 \mathrm{IU} / \mathrm{g}$ of vitamin $\mathrm{E}$. }} \\
\hline${ }^{9}$ Contained $500 \mathrm{IU} / \mathrm{g}$ of premix. & & & & \\
\hline
\end{tabular}

diets for high-producing dairy cows are not conclusive (Firkins et al., 2001).

The objectives of this study were to evaluate production performance, milk fatty acid composition, and nutrient digestibility in high-producing dairy cows consuming diets containing corn and hull-less barley in different proportions as the grain source. We hypothesized that a plausible reduction in production performance would be explained by an altered rumen function, which would be reflected in a reduction of the proportion of de novo fatty acids in milk fat.

\section{MATERIALS AND METHODS}

\section{Animals, Housing, and Diets}

All procedures involving animals were approved by the Institutional Animal Care and Use Committee of
Virginia Tech. Eight primiparous $(580 \pm 41 \mathrm{~kg}$ of BW and $49 \pm 18$ DIM at the beginning of the experiment) and 16 multiparous Holstein cows $(650 \pm 60 \mathrm{~kg}$ of BW and $59 \pm 25$ DIM at the beginning of the experiment) were assigned to 1 of 4 diets (Table 1) in a replicated $4 \times 4$ Latin square design, with 6 independent squares and 21-d periods. Cows were assigned to squares based on parity $(1,2$, and $\geq 3)$ and DIM. To avoid treatment residual effects, cows were randomly assigned to treatments within squares.

Cows were housed in a 24-stall pen within a freestall barn. Cows were fed once daily (1200 h) by means of a Calan gate system (American Calan Inc., Northwood, $\mathrm{NH})$. Cows were trained to find their door for a 2 -wk period before the beginning of the study.

Treatments consisted of diets containing corn (no identity) and hull-less barley grains (cultivar Amaze 10) in different proportions as the grain source (Table 
Table 2. Production performance of dairy cows consuming diets containing different proportions of corn and hull-less barley grain

\begin{tabular}{|c|c|c|c|c|c|c|c|c|c|}
\hline Item & \multicolumn{4}{|c|}{$\operatorname{Diet}^{1}$} & SEM & \multicolumn{4}{|c|}{$P$-value ${ }^{2}$} \\
\hline DMI, kg/d & 26.9 & 24.8 & 24.3 & 25.9 & 0.88 & 0.01 & 0.08 & 0.01 & 0.77 \\
\hline Milk fat, $\%$ & 3.43 & 3.45 & 3.91 & 3.52 & 0.18 & 0.04 & 0.24 & 0.14 & 0.03 \\
\hline Milk protein, \% & 2.98 & 3.07 & 3.05 & 2.99 & 0.06 & 0.33 & - & - & - \\
\hline Milk lactose, \% & 4.81 & 4.84 & 4.82 & 4.80 & 0.04 & 0.58 & - & - & - \\
\hline Milk lactose yield, kg/d & 1.98 & 2.02 & 2.00 & 1.93 & 0.08 & 0.30 & - & - & - \\
\hline MUN, mg/dL & 8.77 & 8.67 & 9.74 & 9.89 & 0.55 & 0.04 & 0.01 & 0.73 & 0.21 \\
\hline $3.5 \% \mathrm{FCM}, \mathrm{kg} / \mathrm{d}$ & 40.3 & 41.3 & 43.5 & 40.0 & 1.53 & 0.04 & 0.78 & 0.02 & 0.11 \\
\hline BW gain, kg/d & 0.78 & 0.81 & 0.84 & 0.66 & 0.24 & 0.71 & - & - & - \\
\hline Feed efficiency, $\mathrm{kg}$ of FCM $/ \mathrm{kg}$ of DMI & 1.53 & 1.70 & 1.81 & 1.58 & 0.07 & 0.01 & 0.20 & 0.01 & 0.18 \\
\hline
\end{tabular}

${ }^{1} 0 \mathrm{~B}=100 \%$ corn grain; $33 \mathrm{~B}=67 \%$ corn grain and $33 \%$ barley grain; $67 \mathrm{~B}=33 \%$ corn grain and $67 \%$ barley grain; $100 \mathrm{~B}=100 \%$ barley grain.

${ }^{2} P$-values for linear (L), quadratic (Q) and cubic (C) effects reported only when diets differed.

2). Diets contained $100 \%$ corn grain (0B), $67 \%$ corn and $33 \%$ hull-less barley grains (33B), 33\% corn and $67 \%$ hull-less barley grains (67B), and $100 \%$ hull-less barley grain (100B). Both cereal grains were ground using a 4.76-mm screen of a hammer mill and incorporated into concentrate pellets at a commercial feed mill (Big Spring Mill Inc., Elliston, VA). Diets were formulated so the grain provided approximately $50 \%$ of the dietary starch and to meet nutrient requirements (NRC, 2001) for a 630-kg lactating dairy cow producing $42 \mathrm{~kg}$ of milk/d.

Concentrate pellets were mixed with corn silage, alfalfa hay, and soybean hulls (Table 2), and delivered ad libitum ( $\sim 5 \%$ refusals) as a TMR. Mixing and delivery was performed using a Calan Data Ranger (American Calan, Inc.). The amount of feed offered and refused was measured daily. Cows were milked twice daily (0100 and $1300 \mathrm{~h}$ ), and milk weights were automatically recorded at each milking. The average of the daily milk yields and DMI from d 10 to 18 of each period was used for statistical analysis.

\section{Nutrient Digestibility}

Total-tract nutrient digestibility was estimated using lanthanum chloride $\left(\mathrm{LaCl}_{3}\right)$ as an external marker (Ferreira et al., 2002). A solution of $\mathrm{LaCl}_{3}\left(0.8 \mathrm{M} \mathrm{LaCl}_{3}\right)$ was prepared by reacting lanthanum oxide $\left(\mathrm{La}_{2} \mathrm{O}_{3}\right)$ with $\mathrm{HCl}$ as follows: (1) $1 \mathrm{~L}$ of distilled water was added to a 4-L Erlenmeyer flask; (2) while stirring, 1,200 mL of concentrated $\mathrm{HCl}$ was added very slowly (as this is an exothermic reaction, $\mathrm{HCl}$ was added in 2 equal fractions with 30-min intervals in between); (3) $750 \mathrm{~g}$ of $\mathrm{La}_{2} \mathrm{O}_{3}$ was added very gently and slowly (as this is a very exothermic reaction, $\mathrm{La}_{2} \mathrm{O}_{3}$ was added in 3 equal fractions with 45-min intervals in between); (4) after apparent solvation, $1 \mathrm{~L}$ of distiller water was added and the solution was stirred overnight; (5) after filtering through grade 1 qualitative filter paper (Whatman, GE Healthcare Bio-Sciences, Pittsburgh, PA), the $\mathrm{LaCl}_{3}$ solution was transferred into a 6 -L calibrated Erlenmeyer flask, and the solution was raised to volume with distilled water; and (7) after transferring to a carboy, $1,272 \mathrm{~mL}$ of distilled water was added to the final solution. The procedure was repeated as necessary to obtain enough marker for the whole experiment. To obtain a final dietary concentration of approximately $40 \mathrm{mg} / \mathrm{kg}$ of DM, $8.65 \mathrm{~kg}$ of the marker solution (density $=1.15$ $\mathrm{g} / \mathrm{mL}$ ) was sprayed onto $909 \mathrm{~kg}$ of soybean hulls.

Fecal grab samples were collected for each period across 3 consecutive days (starting on d 19) at 6-h intervals skipping sampling times $2 \mathrm{~h}$ at the end of each day. Lanthanum concentration was determined in TMR and fecal samples by inductively coupled plasma atomic emission spectroscopy. Samples were prepared as follows (Ferreira et al., 2002): (1) duplicate 2-g samples (TMR and feces) were placed in Pyrex beakers and dry-ashed at $500^{\circ} \mathrm{C}$ for $6 \mathrm{~h}$ (this step was repeated once); (2) the resulting ash was dissolved with $25 \mathrm{~mL}$ of concentrated $\mathrm{HCl}$; (3) after $1 \mathrm{~h}$, the dissolved ashes were transferred to a previously tared specimen cup and diluted to $50 \mathrm{~g}$ by adding lithium hydroxide $(41.7 \mathrm{mM})$; and (4) after an overnight sedimentation, an aliquot of the solution was extracted and analyzed for La concentration.

Dry matter apparent digestibility (DMD) and nutrient apparent digestibility were calculated as described in equations [1] and [2], respectively.

$$
\operatorname{DMD}(\%)=100-\frac{\text { Dietary }[\mathrm{La}]_{(\mathrm{mg} / \mathrm{g} \text { of DM })}}{\text { Fecal }[\mathrm{La}]_{(\mathrm{mg} / \mathrm{g} \text { of DM })}} \times 100, \quad[1]
$$


Nutrient digestibility $(\%)=$

$100-\frac{\text { Dietary }[\mathrm{La}]_{(\mathrm{mg} / \mathrm{g} \text { of DM })}}{\text { Fecal }[\mathrm{La}]_{(\mathrm{mg} / \mathrm{g} \text { of DM })}} \times \frac{\text { Fecal }[\mathrm{Nutr}]_{(\mathrm{g} / \mathrm{g} \text { of DM })}}{\text { Dietary }[\mathrm{Nutr}]_{(\mathrm{g} / \mathrm{g} \text { of } \mathrm{DM})}} \times 100$,

where $[\mathrm{La}]=$ La concentration and $[\mathrm{Nutr}]=$ nutrient concentration.

\section{Sample Collection and Analysis}

Samples of feed ingredients and feed refusals were collected weekly. All samples were dried in a forced-air oven $\left(55^{\circ} \mathrm{C}\right)$ until constant weight and ground to pass through a 1-mm screen of a Wiley mill (Thomas Scientific, Swedesboro, NJ). Crude protein concentration was calculated as percent $\mathrm{N} \times 6.25$ after combustion analysis using a Vario El Cube CN analyzer (Elementar Americas Inc., Mount Laurel, NJ). The concentration of NDF was determined using the Ankom200 Fiber Analyzer (Ankom Technology, Macedon, NY) with sodium sulfite and $\alpha$-amylase (Ankom Technology). Starch concentration was determined using the acetate buffer method of Hall (2009) with $\alpha$-amylase from Bacillus licheniformis (FAA, Ankom Technology) and amyloglucosidase from Aspergillus niger (E-AMGDF, Megazyme International, Wicklow, Ireland). Ash concentration was determined after burning feed samples in a furnace $\left(3 \mathrm{~h}\right.$ at $\left.550^{\circ} \mathrm{C}\right)$.

Milk samples (a.m. and p.m. milkings) were collected on d 17 and 18 for determination of milk fat, protein, lactose, and milk urea nitrogen concentrations with a CombiFoss FT+ Fourier transform infrared analyzer (Foss, Hillerød, Denmark) by United DHIA (Radford, VA). An additional milk sample (a.m. and p.m. milking) was collected on d 18 to determine milk fatty acid composition. Milk fatty acids were extracted and methylated according to the method of Chouinard et al. (1999). Fatty acid methyl esters were analyzed by gas chromatography (Agilent 6890 N GC) using a CP-Sil 88 capillary column $(100 \mathrm{~m} \times 0.25 \mathrm{~mm}$ i.d. with $0.2-\mu \mathrm{m}$ thickness; Varian Inc., Palo Alto, CA). The oven temperature was initially set at $80^{\circ} \mathrm{C}$, and was increased at $2^{\circ} \mathrm{C} / \mathrm{min}$ to $190^{\circ} \mathrm{C}$ and maintained for $9 \mathrm{~min}$. Inlet and flame-ionization detector temperatures were $250^{\circ} \mathrm{C}$, the split ratio was 100:1, and a $1-\mu \mathrm{L}$ injection volume was used. The hydrogen carrier gas flow rate was $1 \mathrm{~mL} / \mathrm{min}$. Hydrogen flow to the detector was $25 \mathrm{~mL} / \mathrm{min}$, airflow was $400 \mathrm{~mL} / \mathrm{min}$, and the flow of nitrogen makeup gas was $40 \mathrm{~mL} / \mathrm{min}$. Fatty acid peaks were identified by using pure methyl ester standards $(\mathrm{Nu}-$ Chek Prep Inc., Elysian, MN). A butter reference standard (BCR 164; Commission of the European Communities, Community Bureau of Reference, Brussels, Belgium) was analyzed at regular intervals to determine recoveries and correction factors for individual fatty acyl composition in milk fat.

\section{Statistical Analysis}

All variables were analyzed using the MIXED procedure of SAS (version 9.3, SAS Institute Inc., Cary, NC). The statistical model included the effects of square (fixed; $\mathrm{df}=5$ ), treatment (fixed; $\mathrm{df}=3$ ), square by treatment interaction (fixed; $\mathrm{df}=15$ ), period (random; $\mathrm{df}=3$ ), and cow within square (random; $\mathrm{df}=18$ ) and the random residual error. After detecting significant differences $(P<0.05)$, treatments were tested for linear, quadratic and cubic effects. For those variables with significant quadratic effects, the optimum proportion of corn and barley grains was determined with the REG procedure of SAS. The model to quantify the intercept and the coefficients for a quadratic regression model (Broderick and Radloff, 2004) included the proportion of hull-less barley $(x)$ and the proportion of hull-less barley to the power of $2\left(x^{2}\right)$. The optimal proportion of hull-less barley was determined solving the first derivative of a quadratic function.

\section{RESULTS AND DISCUSSION}

Hull-less barley grain contained $3.2 \%$ ash, $14.3 \%$ CP, $12.6 \% \mathrm{NDF}$, and $58.2 \%$ starch. Ash and CP concentrations were slightly higher or similar, whereas the starch concentration was slightly lower than or similar to values previously reported for hull-less barley grains (Griffey et al., 2010; Yang et al., 2013a). Compared with the corn grain used in this study, hull-less barley grain had a higher concentration of $\mathrm{CP}$ and NDF and a lower concentration of starch (8.8 vs. $14.3 \% \mathrm{CP}, 10.6$ vs. $12.6 \% \mathrm{NDF}$, and 65.4 vs. $58.2 \%$ starch for corn and hull-less barley grains, respectively). Differences in nutritional composition of the grains resulted in minor differences in the composition of the diets. The major difference among diets was starch concentration, which ranged from 28.2 to $30.7 \%$ (Table 1).

Dry matter intake differed quadratically among treatments $(P<0.01)$, being lowest for $67 \mathrm{~B}$ and highest for $0 \mathrm{~B}$ and 100B (Table 2). The reasons for this quadratic response are not clear. If we consider that starch fermentation rate in the rumen is faster for barley grains than for corn (Herrera-Saldana et al., 1990; Yang et al., 1997a), and therefore DMI would be lower for diets containing barley grain, we do not find a clear explanation for the higher DMI observed when feeding $100 \mathrm{~B}$ relative to $33 \mathrm{~B}$ or $67 \mathrm{~B}$. As DMI was greater than $3.9 \% \mathrm{BW}$ for all treatments, which is greater than DMI previously reported ( $<3.6 \%$ BW; Yang et al., 1997a,b), 
we consider a negative metabolic effect of treatments on DMI to be unlikely in this study.

Feeding hull-less barley did not affect milk yield $(P$ $<0.98$; Table 2). Different from this study, Yang et al. (1997a) observed a $1.8 \mathrm{~kg} / \mathrm{d}$ decrease in milk yield for cows fed diets containing hull-less barley grain relative to cows fed diets containing corn grain. In another study, Yang et al. (1997b) observed a $1.4 \mathrm{~kg} / \mathrm{d}$ numerical, but not statistically significant, decrease in milk yield when feeding hull-less barley relative to corn. Although the reasons for the different results among studies are not clear, the dietary starch concentration in this study was substantially lower than in previous studies (Yang et al., 1997a,b). Also, milk production differed substantially between this study $(>40 \mathrm{~kg} / \mathrm{d})$ and those previously reported $(\leq 30 \mathrm{~kg} / \mathrm{d}$; Yang et al., 1997a,b). In this study, a higher demand for glucose precursors (e.g., propionate and lactate) could have minimized differences in the metabolism of carbohydrates.

Milk fat concentration differed cubically among treatments $(P<0.03$; Table 2$)$. The cubic response is attributed to the higher milk fat concentration observed for 67B. Milk fat concentration did not change among the other 3 diets. Firkins et al. (2001) reported an inverse relationship between milk fat concentration and DMI. Accordingly, the high milk fat concentration observed for cows fed the 67B diet in this study could be related to the lower DMI. Neither the concentrations in milk of protein $(P<0.33)$ and lactose $(P<0.58)$ nor the yields of protein $(P<0.23)$ and lactose $(P<0.30)$ differed among treatments. Feeding hull-less barley increased MUN concentration linearly $(P<0.01)$. This pattern followed the increasing $\mathrm{CP}$ concentrations as hull-less barley replaced corn in the diet. Body weight was similar among diets $(P<0.71)$.

Under the assumption that feeding hull-less barley grain increases the ruminal fermentability of starch (Herrera-Saldana et al., 1990; Yang et al., 1997a), we hypothesized that the proportion of de novo fatty acids in milk would be diminished when feeding hull-less barley grain. Contrary to our hypothesis, the proportion of de novo synthesized fatty acids in milk did not differ among treatments (Table 3). The concentration of a few specific fatty acids, such as C15:0, C16:0, trans-12 C18:1, and trans-10,cis-12 CLA, differed linearly or cubically (Table 3). However, these differences were marginal and have minimum biological implications.

Table 3. Fatty acid profile (g/100 g of fat) in milk fat from dairy cows consuming diets containing different proportions of corn and hull-less barley grain

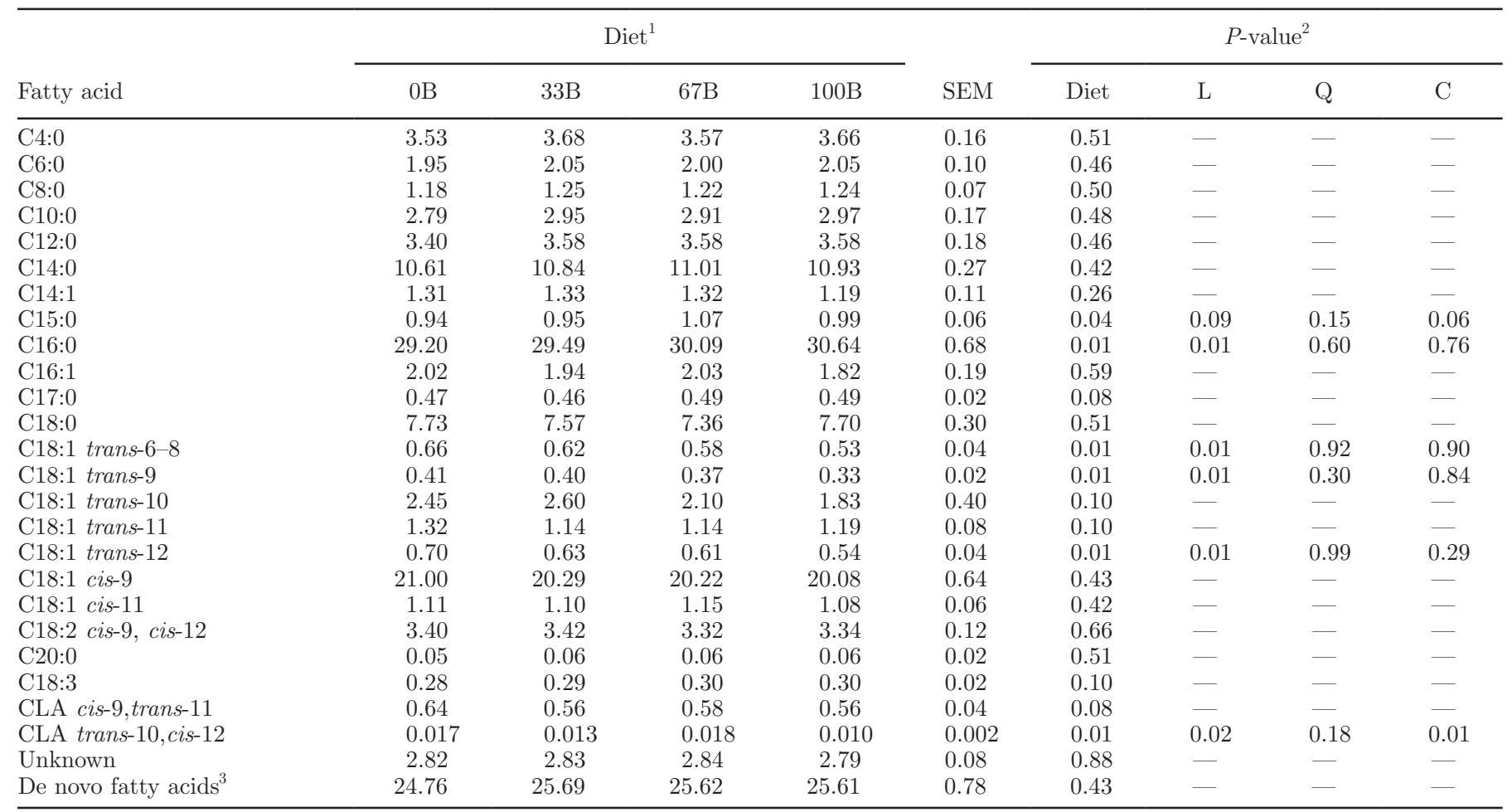

${ }^{1} 0 \mathrm{~B}=100 \%$ corn grain; $33 \mathrm{~B}=67 \%$ corn grain and $33 \%$ barley grain; $67 \mathrm{~B}=33 \%$ corn grain and $67 \%$ barley grain; $100 \mathrm{~B}=100 \%$ barley grain.

${ }^{2} P$-values for linear (L), quadratic (Q) and cubic (C) effects reported only when diets differed.

${ }^{3}$ De novo fatty acids is the sum of C4:0 to C14:0. 
Table 4. Apparent digestibility of dairy cows consuming diets containing different proportions of corn and hull-less barley grain

\begin{tabular}{|c|c|c|c|c|c|c|c|c|c|}
\hline \multirow[b]{2}{*}{ Item } & \multicolumn{4}{|c|}{$\operatorname{Diet}^{1}$} & \multirow[b]{2}{*}{ SEM } & \multicolumn{4}{|c|}{$P$-value ${ }^{2}$} \\
\hline & 0B & $33 \mathrm{~B}$ & $67 \mathrm{~B}$ & 100B & & Diet & $\mathrm{L}$ & $\mathrm{Q}$ & $\mathrm{C}$ \\
\hline DM, \% & 62.1 & 61.3 & 61.1 & 61.4 & 1.80 & 0.82 & - & - & - \\
\hline CP, \% & 60.3 & 60.5 & 61.0 & 62.4 & 1.89 & 0.28 & - & - & - \\
\hline NDF, $\%$ & 38.7 & 36.6 & 35.6 & 38.3 & 3.71 & 0.38 & - & - & - \\
\hline Starch, \% & 97.3 & 97.7 & 97.9 & 97.7 & 0.17 & 0.01 & 0.01 & 0.02 & 0.90 \\
\hline
\end{tabular}

For example, the proportion ( $\mathrm{g} / 100 \mathrm{~g}$ of fatty acid) of trans-10,cis-12 CLA was substantially lower than values observed for cows infused with trans-10, cis-12 CLA to induce milk fat depression (Lock et al., 2007; Harvatine and Bauman, 2011). Based on these observations and on the total milk fat concentrations (Table 2), we disregard the possibility that any of the treatments of this study had a negative effect on de novo milk fatty acid synthesis.

Nutrient utilization did not differ or differed only minimally among treatments (Table 4$)$. The apparent total-tract digestibility of DM $(P<0.82), \mathrm{CP}(P<$ $0.28)$, and NDF $(P<0.38)$ did not differ among treatments. The apparent total-tract digestibility of starch increased quadratically, being maximum $(97.9 \%)$ for 67B. Despite the latter response, the magnitude of the differences $(<1 \%)$ in starch digestibility is biologically trivial, especially when digestibility of starch was almost complete ( $>97 \%$ starch digestibility). We attribute the almost complete digestibility of starch to the inclusion of both grains into the pelleted concentrate, which ensures an intense processing of the endosperm (Yang et al., 2000). This intense processing could also explain the similar milk production among treatments. In a study in which grains were steam-rolled (Yang et al., 1997a), milk yield and starch digestibility were greater for cows fed diets containing corn grain than for cows fed diets containing hull-less barley grain. As starch digestibility in that study was incomplete $(<95 \%)$, it is possible that differences nutrient utilization among treatments are minimized when cereal grains are intensively processed.

Evaluating the use of hull-less barley in diets for lactating dairy cows could have a major effect in dairy farming systems. When drought stress occurs, one immediate effect is an increase in corn prices (USDA, $2012 \mathrm{a}, \mathrm{b})$ and a reduction in net farm income due to increased feed costs. For example, corn price increased from $\$ 6.37$ per bushel $(\$ 250 / \mathrm{Mg})$ in June 2012 (USDA, $2012 \mathrm{a})$ to $\$ 7.63$ per bushel $(\$ 300 / \mathrm{Mg})$ in August 2012
(USDA, 2012b), when drought stress was most extreme. Increased feed prices translate into greater feed costs in dairy farming systems, which may reduce income over feed costs and profitability. When corn prices increase, alternative feeding strategies, such as increasing the proportion of forage in the diet or increasing the inclusion of by-products, are frequently evaluated for feeding programs (Mullins et al., 2010; Sullivan et al., 2012; Hall and Chase, 2014). Another alternative is replacing corn grain with other less expensive cereal grains, such as barley, oats, sorghum, or wheat. According to USDA (2016), the price $(\$ / \mathrm{bu})$ of corn grain has been $18 \%$ greater than the price of barley for the last $15 \mathrm{yr}$. As specific densities for corn and hulled barley grains differ (56 and $48 \mathrm{lb} / \mathrm{bu}$, respectively), the difference of grain prices on a per ton basis might be marginal, depending on market situations (Figure 1). A mature market for hull-less barley is not established. However, based on this study, the inclusion of hull-less barley in diets for dairy cows could reduce feeding costs while sustaining production performance at times of high demand for corn grain.

\section{CONCLUSIONS}

The inclusion of hull-less barley grain (cultivar Amaze 10 ) as an energy source in diets for high-producing dairy cows resulted in similar production performance and nutrient utilization as for corn grain. Also, to optimize FCM yield and feed efficiency, hull-less barley should be included as $56.7 \%$ of the total grain. Contrary to our expectations, hull-less barley did not affect milk fatty acid composition, suggesting that rumen metabolism did not differ when replacing corn with hull-less barley. Overall, this study indicates that hull-less barley grain is as good as corn grain as an energy source, and that there is no need to increase the concentration of NDF when formulating diets for high-producing dairy cows including hull-less barley. 


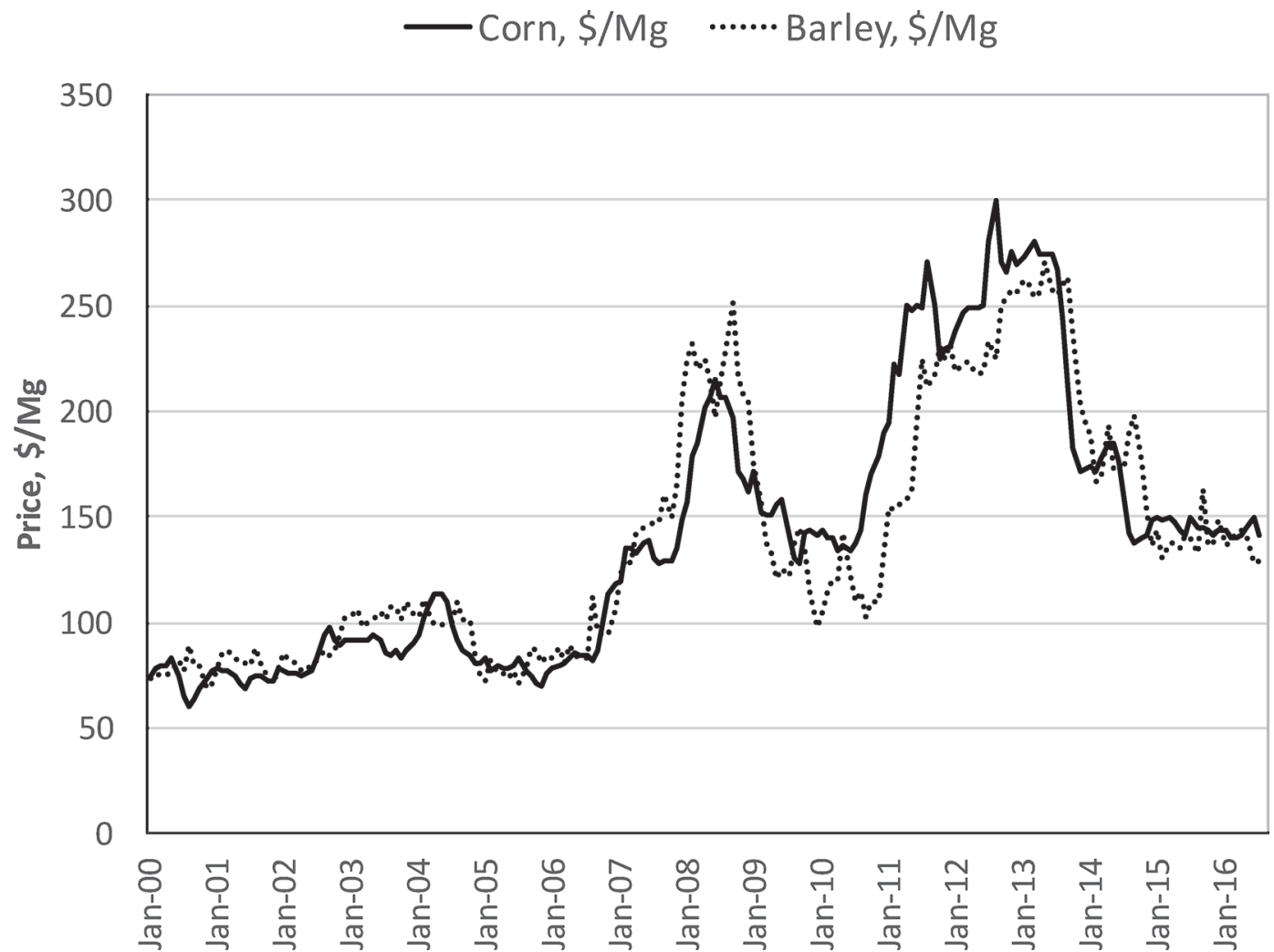

Figure 1. Market prices for corn and hulled barley grains (adapted from USDA, 2016) from 2000 to 2016.

\section{ACKNOWLEDGMENTS}

We are grateful to Virginia Tech undergraduate students Kristina Anderson (Agriculture and Applied Economics), Emily Richardson (Animal and Poultry Sciences), Kaitlyn Sonifrank (Dairy Science), and Vivian Yang (Dairy Science) for their help feeding cows and collecting fecal samples. This project was funded mainly by the John Lee Pratt Endowment from the College of Agriculture and Life Sciences at Virginia Tech, and partially by USDA-NIFA Hatch Project VA160025 and USDA-NIFA Multistate Project VA-136291 (NC-2042, Management Systems to Improve the Economic and Environmental Sustainability of Dairy Enterprises).

\section{REFERENCES}

Beauchemin, K. A. 1991. Effects of dietary neutral detergent fiber concentration and alfalfa hay quality on chewing, rumen function, and milk production of dairy cows. J. Dairy Sci. 74:3140-3151.

Broderick, G. A., and W. J. Radloff. 2004. Effect of molasses supplementation on the production of lactating dairy cows fed diets based on alfalfa and corn silage. J. Dairy Sci. 87:2997-3009.

Chouinard, P. Y., L. Corneau, A. Saebo, and D. E. Bauman. 1999. Milk yield and composition during abomasal infusion of conjugated linoleic acids in dairy cows. J. Dairy Sci. 82:2737-2745.
Fellner, V., J. C. Burns, and D. S. Marshall. 2008. Effect of feeding corn, hull-less or hulled barley on fermentation by mixed cultures of ruminal microorganisms. J. Dairy Sci. 91:1936-1941.

Ferraretto, L. F., P. M. Crump, and R. D. Shaver. 2013. Effect of cereal grain type and corn grain harvesting and processing methods on intake, digestion, and milk production by dairy cows through a meta-analysis. J. Dairy Sci. 96:533-550.

Ferreira, G. and D. R. Mertens. 2005. Chemical and physical characteristics of corn silages and their effects on in vitro disappearance. J. Dairy Sci. 88:4414-4425.

Ferreira, G., D. R. Mertens, P. Berzaghi, and R. D. Shaver. 2002. Effect of corn silage maturity and crop processing on performance of dairy cows. J. Dairy Sci. 85(Suppl. 1):94. (Abstr.)

Firkins, J. L., M. L. Eastridge, N. R. St-Pierre, and S. M. Noftsger. 2001. Effects of grain variability and processing on starch utilization by lactating dairy cattle. J. Anim. Sci. 79(E-Suppl.):E218E238.

Griffey, C., W. Brooks, M. Kurantz, W. Thomason, F. Taylor, D. Obert, R. Moreau, R. Flores, M. Sohn, and K. Hicks. 2010. Grain composition of Virginia winter barley and implications for use in feed, food, and biofuels production. J. Cereal Sci. 51:41-49.

Hall, M. B. 2009. Determination of starch, including maltooligosaccharides, in animal feeds: Comparison of methods and a method recommended for AOAC Collaborative Study. J. AOAC Int. 92:42-49.

Hall, M. B., and L. E. Chase. 2014. Responses of late-lactation cows to forage substitutes in low-forage diets supplemented with byproducts. J. Dairy Sci. 97:3042-3052.

Harvatine, K. J., and D. E. Bauman. 2011. Characterization of the acute lactational response to trans-10, cis-12 conjugated linoleic acid. J. Dairy Sci. 94:6047-6056.

Herrera-Saldana, R. E., J. T. Huber, and M. H. Poore. 1990. Dry matter, crude protein, and starch degradability of five cereal grains. J. Dairy Sci. 73:2386-2393. 
Lock, A. L., C. Tyburczy, D. A. Dwyer, K. J. Harvatine, F. Destaillats, Z. Mouloungui, L. Candy, and D. E. Bauman. 2007. Trans-10 octadecenoic acid does not reduce milk fat synthesis in dairy cows. J. Nutr. 137:71-76.

Mullins, C. R., K. N. Grigsby, D. E. Anderson, E. C. Titgemeyer, and B. J. Bradford. 2010. Effects of feeding increasing levels of wet corn gluten feed on production and ruminal fermentation in lactating dairy cows. J. Dairy Sci. 93:5329-5337.

NRC. 2001. Nutrient Requirements of Dairy Cattle. 7th rev. ed. Natl. Acad. Press, Washington, DC.

Nocek, J. E., and S. Tamminga. 1991. Site of digestion of starch in the gastrointestinal tract of dairy cows and its effect on milk yield and composition. J. Dairy Sci. 74:3598-3629.

Overton, T. R., M. R. Cameron, J. P. Elliott, J. H. Clark, and D. R. Nelson. 1995. Ruminal fermentation and passage of nutrients to the duodenum of lactating cows fed mixtures of corn and barley. J. Dairy Sci. 78:1981-1998.

Sullivan, M. L., K. N. Grigsby, and B. J. Bradford. 2012. Effects of wet corn gluten feed on ruminal $\mathrm{pH}$ and productivity of lactating dairy cattle fed diets with sufficient physically effective fiber. J. Dairy Sci. 95:5213-5220.

Thomason, W. E., W. S. Brooks, C. A. Griffey, and M. E. Vaughn. 2009. Hulless barley seeding rate effects on grain yield and yield components. Crop Sci. 49:342-346.

USDA. 2012a. Agricultural Prices (July 2012). USDA National Agricultural Statistics Service, Washington, DC.
USDA. 2012b. Agricultural Prices (September 2012). USDA National Agricultural Statistics Service, Washington, DC.

USDA. 2016. Feed grains data: Yearbook tables (September 2016). National Agricultural Statistics Service, Washington, DC. Accessed Oct. 12, 2016. http://www.ers.usda.gov/data-products/ feed-grains-database/feed-grains-yearbook-tables.aspx.

Yang, L., D. A. Christensen, J. J. McKinnon, A. D. Beattie, and P. Yu. 2013a. Effect of altered carbohydrate traits in hulless barley (Hor deum vulgare $\mathrm{L}$.) on nutrient profiles and availability and nitrogen to energy synchronization. J. Cereal Sci. 58:182-190.

Yang, L., D. A. Christensen, J. J. McKinnon, A. D. Beattie, and P. Yu. 2013b. Predicted truly absorbed protein supply to dairy cattle from hulless barley (Hordeum vulgare L.) with altered carbohydrate traits with multi-year samples. J. Cereal Sci. 58:372-379.

Yang, W. Z., K. A. Beauchemin, B. I. Farr, and L. M. Rode. 1997a. Comparison of barley, hull-less barley, and corn in the concentrate of dairy cows. J. Dairy Sci. 80:2885-2895.

Yang, W. Z., K. A. Beauchemin, K. M. Koenig, and L. M. Rode. 1997b. Comparison of hull-less barley, barley, or corn for lactating cows: effects on extent of digestion and milk production. J. Dairy Sci. 80:2475-2486.

Yang, W. Z., K. A. Beauchemin, and L. M. Rode. 2000. Effects of barley grain processing on extent of digestion and milk production of lactating cows. J. Dairy Sci. 83:554-568. 